\title{
Horsemeat in the culinary traditions of the Mishär Tatar diaspora in the eastern Baltic Sea region: cultural and historical aspects
}

\author{
Ingvar Svanberg ${ }^{1 *}$, Sabira Ståhlberg ${ }^{1}$ and Renat Bekkin ${ }^{2,3}$
}

\begin{abstract}
Hippophagy is still unthinkable in many European countries, but in the Mishär Tatar culinary tradition, horsemeat products play an important role. Part of the Mishär Tatars, originally from Nizhny Novgorod province (Russia), migrated to the eastern Baltic Sea region in the nineteenth and early twentieth century. They continued to slaughter horses and eat horseflesh, despite being opposed and stigmatized by the majority in their new surroundings. Today, home slaughtering has disappeared, and the tradition focuses mainly on sausages prepared for domestic consumption or bought in food stores. Horsemeat is today considered a delicacy and an important aspect of commensality among Mishär Tatars. There is a small and persistent market for horseflesh products in the eastern Baltic Sea area, mainly Finland, Saint Petersburg (Russia), Estonia, and Latvia. Hippophagy continues to play an important role for the diaspora Mishär Tatar identity and the preservation of traditional narrative and culture, and so far it has resisted all adaptation attempts in the majority societies, where horsemeat is frowned upon.
\end{abstract}

Keywords: Commensality, Food-cultural studies, Food ways, Halal, Heritage food, Hippophagy, Human-horse relationship, Sausages

\section{Introduction}

To eat for pleasure, rather than for survival, is probably the most important factor behind human food culture and the development of food habits. We prefer to consume foods with a story, especially when they are also useful for the body [1]. Some foods have high nutritional and emotional value, such as horseflesh, yet traditionally hippophagy has been taboo in most of Europe and North America [2-4]. While horseflesh is forbidden by Jewish dietary laws (Leviticus 11:3), Sunni Islam permits it [2]. Although horsemeat is nowadays consumed in several industrialized countries, often as a result of information campaigns, it is still disgusting to many individuals. In some countries, it is even illegal to consume horseflesh [2]. In Western and Northern Europe, hunger was previously preferred to eating horses,

\footnotetext{
* Correspondence: ingvar.svanberg@ires.uu.se

${ }^{1}$ Institute for Russian and Eurasian Studies, Uppsala University, Box 514,

SE-751 20 Uppsala, Sweden

Full list of author information is available at the end of the article
}

which were considered unsuitable for human consumption for different reasons [4-6]. Only certain outcasts and minorities slaughtered horses and consumed them, but the horse killer was a despised person, stigmatized in the community $[5,7]$. Only the Saami in the far north, Hungarian horse herdsmen and several groups in Eastern Europe had no taboos against horsemeat [8-10].

\section{Hippophagy in Eurasia}

While Western Europeans generally refuse to consume horseflesh, Turkic and Mongolian nomads and their present-day settled descendants are fond of the meat. Enlightenment period travelers and researchers, interested in improving domestic diets and combating famine, noted horseflesh consumption both among nomads and settled groups. A mixture of fascination and abhorrence toward hippophagy has always been prevalent among the European travelers, but hippophagy has been and still is part of the culinary traditions among many peoples in northern and

(c) The Author(s). 2020 Open Access This article is licensed under a Creative Commons Attribution 4.0 International License, which permits use, sharing, adaptation, distribution and reproduction in any medium or format, as long as you give appropriate credit to the original author(s) and the source, provide a link to the Creative Commons licence, and indicate if changes were made. The images or other third party material in this article are included in the article's Creative Commons licence, unless indicated otherwise in a credit line to the material. If material is not included in the article's Creative Commons licence and your intended use is not permitted by statutory regulation or exceeds the permitted use, you will need to obtain permission directly from the copyright holder. To view a copy of this licence, visit http://creativecommons.org/licenses/by/4.0/. 
central Eurasia, including the Kazak and Kyrghyz [2, 11, 12]. The Altaians in Siberia bought horses from Russians for food until fairly recently [13]. The Russian peasants despised horsemeat, which they considered an "ungodly abomination", as one observer put it, and they would rather starve to death than to eat a horse [12].

In 1785, Turkic Noghay Tatars, roaming the steppe north of the Black Sea, thought horseflesh "their best choice, as they think both oxen and sheep are fad and tasteless", according to the Swedish scientist Bengt Bergius [14]. The French-Polish engineer and cartographer Sieur de Beauplan found in 1780 that wild horsemeat lacked taste, but the Tatars considered it and especially foal meat a great delicacy, and the head was given to the most influential individuals [15]. The Noghay Tatars preferred horsemeat especially in winter; intestines were filled with horse ribs, meat, and fat and then smoked. Only men prepared and ate the finely chopped horsemeat, fat, and intestines in a broth (turai). They used fingers to take the meat pieces out from the pot and squeezed the pieces before eating. Horsemeat sausage, $k a z y$, is also spelled kazi, qazl, or qazy and the name exists in many Turkic languages [16].

The Western Mongolian Kalmyk nomads, roaming near the Caspian Sea, considered horseflesh superior to all other kinds of meat, according to the German traveler Benjamin Bergmann in 1804 [17]. The Swedish explorer Johan Peter Falck noted in the 1770s that only the Buddhist monks did not eat horsemeat, but all other Kalmyks consumed horseflesh and even self-dead animals [18]. In the Ural Mountains, Falck heard about a case in 1771 relating to a sick horse, which had been left in the care of a Meshcheryak (a Tatarized group of mixed origin, later assimilated by the Bashkir in the Ural region). The man had eaten his patient. He excused himself saying that the horse was close to death anyway and promised to deliver the fur to the owner. Most Meshcheryak, noted Falck, were clothed in horse furs with the mane on the back, and they looked "completely wild" [19].

\section{Volga Tatars and their horses}

In the Volga region in European Russia, Mishär Tatars have appreciated horseflesh in their cuisine for several centuries. Johan Peter Falck mentioned that the Tatars along the Volga River bred especially fine and big horses [18]. Kazan Tatars were "wonderful horse breeders", noted also the German traveler Franz Erdmann in 1859. The women took care of the horses in the stable, in contrast to most other Turkic and Mongolian peoples, where the horses are a mainly male occupation [20].

Early Tatar history is connected with Central Asia and Siberia; Turkic groups migrated from the east to the Volga area until at least the seventeenth century [21]. Their main livelihood was agriculture and animal breeding. From the nineteenth century, when agricultural and pasture lands had become increasingly scarce, Tatars from villages in the Nizhny Novgorod province, mainly Mishär (in English often spelled Mishar) and Kasimov Tatars, turned to trade and began moving in larger groups to the bigger cities of the Russian Empire. The Mishär Tatars speak a specific Tatar language, considered to be a dialect of the Kazan Tatar language. Their origins have not been conclusively mapped out, and their numbers are unknown. Mishär Tatars live today in several regions in Russia, mainly south of the Volga River, and since a century they also form a diaspora in the Baltic Sea region (chiefly Finland, Estonia, Latvia, and Sweden). Smaller groups of Mishär Tatars live on at least three continents outside Europe (North America, Asia, and Australia) [22].

At the end of the nineteenth century, Mishär Tatars moved westwards from the capital Saint Petersburg to trade in towns in the eastern Baltic Sea region. After the Bolsheviks came to power in 1917, a few thousand Mishär Tatars remained and created a diaspora in the newly founded states of Finland, Estonia, and Latvia; some moved onwards to Sweden, Germany, and other countries. The Tatars in Lithuania belong to a much earlier migration [22]. Mishär Tatar horse slaughtering and horsemeat consumption traditions have remained until today in the eastern Baltic Sea region, although the Tatars in many other aspects have adapted to the majority societies (Fig. 1 (map)).

\section{Objectives, sources, and method}

This article discusses the process of urbanizing Mishär Tatar village traditions of horse slaughtering and horsemeat consumption in Saint Petersburg (Russia) and Finland, and to a lesser degree in Estonia and Latvia, within the context of a largely anti-horseflesh majority society and economy. Tatar cultural adaptation is highlighted through the discourse about horsemeat consumption, which is part of the efforts to preserve a specific identity in the diaspora. Commensality, the act of eating together, is an important characteristic of Tatar communities and horseflesh was consumed not only during festivities, but also in gatherings of families, relatives, neighbors, and friends, who often cooperated in the horse slaughtering [23]. The changes in the importance of horseflesh in modern Tatar cuisine are also described.

The historical perspective is constructed from scattered narratives in ethnographic literature and travelogues. For more recent history, interviews and field notes provide the main sources. The source material is not very large nor very broad. Ethnographic descriptions for instance about horse slaughter among Mishär Tatars in village conditions are very rare and mentioned only briefly in travelers' and ethnologists' reports. The modern diaspora narratives are reviewed, contrasted, and analyzed against the background of the few scientific studies published in Russia on Tatar 


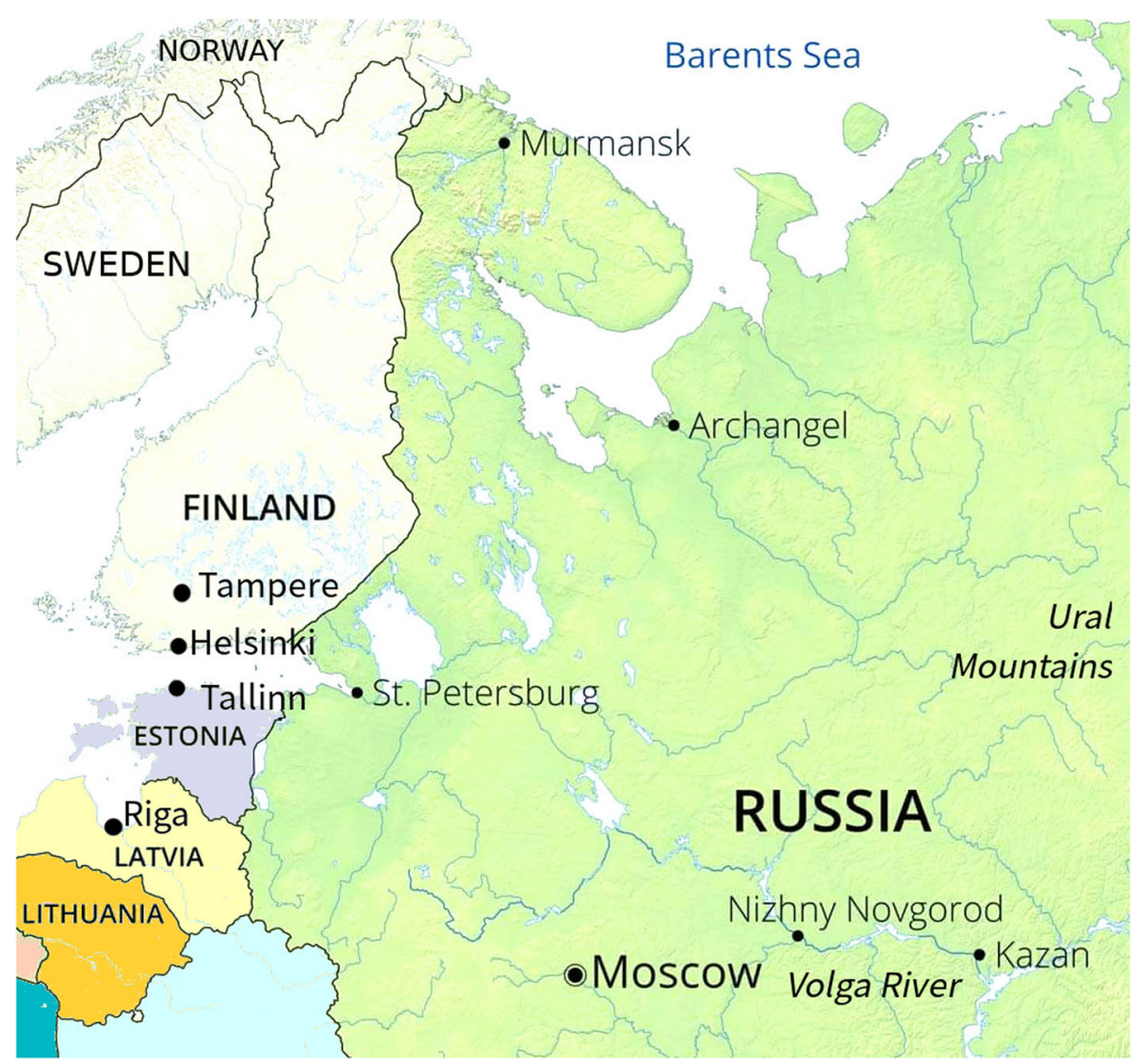

Fig. 1 The settlements of the Kazan, Kasimov, and Mishär Tatars are located in and around Kazan (Tatarstan) and in the Nizhny Novgorod province south of the Volga River. The migration of Mishär Tatars from the Volga region took place in the late nineteenth and early twentieth century. Larger diaspora settlements are found in Saint Petersburg and Moscow in Russia, Estonia (mainly Tallinn), Latvia (Riga), and Finland (Helsinki, Tampere, and Järvenpää). Saint Petersburg functioned as the starting point for the Mishär Tatars from several villages in the Nizhny Novgorod province, who traded and settled in the eastern Baltic Sea region. Some Mishär Tatars also live in Sweden and Germany, but their numbers are very few today. The Tatars in Poland and Lithuania are the descendants of earlier Tatar migrations. Courtesy of the Nations Online Project, to the map has been added a few towns and cities where Mishär Tatars

live, https://www.nationsonline.org/oneworld/map/European-Russia-map.htm

horseflesh traditions. They illustrate clearly the separate lines of development, which have occurred in the different diaspora groups. This article uses the methods of ethnobiology and specifically of historical ethnobiology, focusing on human usage of the natural environment, and development of the relation between humans and their surroundings [24].

\section{Results}

Village traditions, religion, and horse slaughter

A "good" kill of an animal varies according to culture, and it has different rules, codes, and ideologies as well as practical and material issues [25]. Mishär Tatars are traditionally Sunni Muslims. Strict adherents to Islam consider religion a hindrance to eating pork or non-halal meat, but Mishär Tatars do not necessarily follow the Muslim restrictions and even pigs can be found in the backyard of their village houses. A century ago, however, slaughter was done according to the Muslim tradition, if possible. The Mishär Tatars did not commonly use the word "halal" (food permitted by Islamic law) until some decades ago, and there was no specific food production industry connected with religion until recently. Today, new Muslim immigrants have made halal meat available, but Tatars remain largely indifferent to it [26, 27]. In Russia, Finland, Estonia, and Latvia, halal has now become a specific meat product market, which serves a great variety of ethnic and religious groups [28].

Among the Kazan Tatars further east along the Volga River, consumption of horsemeat is not as common as among the Mishär. Tatar city dwellers and peasants in the nineteenth century preferred sheep and seldom ate beef or horsemeat, except for celebrations like marriages [20]. Festivity dishes in Kazan, the capital of Tatarstan, still today include minced and cooked mutton and a little horsemeat, but also birds like geese for weddings [16]. Symbolism was 
very important previously: in the surroundings of Kazan, Tatar peasants prepared a horsemeat dish (bumbar or tuterma) for weddings by cleaning the intestines, filling them with gruel and serving them with viscera to symbolize the bride's future pregnancy [20]. Today, horsemeat products can be easily found in Kazan and other cities in Tatarstan (for instance in the Bakhetle hypermarket chain there is a large assortment of horsemeat dishes). Also in almost any store of halal products in Russia, at least dried horse sausages can be found [29-31].

\section{Urbanization: Saint Petersburg slaughterhouses}

In the nineteenth century, as a result of demographic growth, increasing scarcity of land and political changes limiting occupations, Mishär Tatars from the Nizhny Novgorod and neighboring Tambov and Ryazan provinces began trading in nearby towns and soon also in the capital of the Russian Empire, Saint Petersburg. Tatars and Muslims from other parts of the empire were already present in the metropolis since its establishment in 1703. Horse was an important ingredient in the peasant Mishär Tatar cuisine and to provide horsemeat for the growing urban Tatar population became a challenge and a new market niche. Tatar merchants were quick to observe the need for horseflesh and established slaughterhouses in Saint Petersburg and in a few other towns such as Tallinn in Estonia [32, 33] (Fig. 2).

In Saint Petersburg, horse slaughterhouses were commonly located in or around the southern part of the city. One of the first establishments was located on the Krestovsky Island. There horses were slaughtered in accordance with the Muslim ritual until the middle of the nineteenth century [34]. After the turn of the century, the name "Tatar Island" still continued to be used by local residents and summer visitors. Slaughterhouses could also be found near horse fairs. Opposite the Voskresensky Novodevichy Monastery was the Horse Square (Konnaya ploschad), where on Sundays, Wednesdays, and Fridays a horse fair and races were held. Horses were sold for slaughter in this area until the beginning of the twentieth century [35]. Another fair took place at the Obvodny Canal, and the most notable buyers were Tatars, who specialized in slaughter (Russian koneboitsy) [36].

Horse slaughtering became a profitable business in Saint Petersburg [35]. Complaints about violation of sanitary standards, rotten, infected, and stinking meat or selling a horse carcass to the zoological garden, caused the city authorities repeatedly-however with little success-to try to close the Tatar-owned slaughterhouses or transfer them to new owners [34]. Other entrepreneurs also became interested, when the business flourished. Among them were Russians, who at first were refused, with a reference to the expertise of Tatars in horse slaughtering. The authorities finally decided to tighten sanitary control and a municipal horse slaughterhouse was opened at the corner of Al'buminnaya Street (since 1965 Krasutsky Street) and Zabalkansky Prospekt (now Moskovsky Prospekt) in July 1892. Equipped with modern technology, it was designed to provide horsemeat consumers with safe and controlled quality products. This horse slaughterhouse continued to serve clients until the end of the 1920s [35] (Fig. 3).

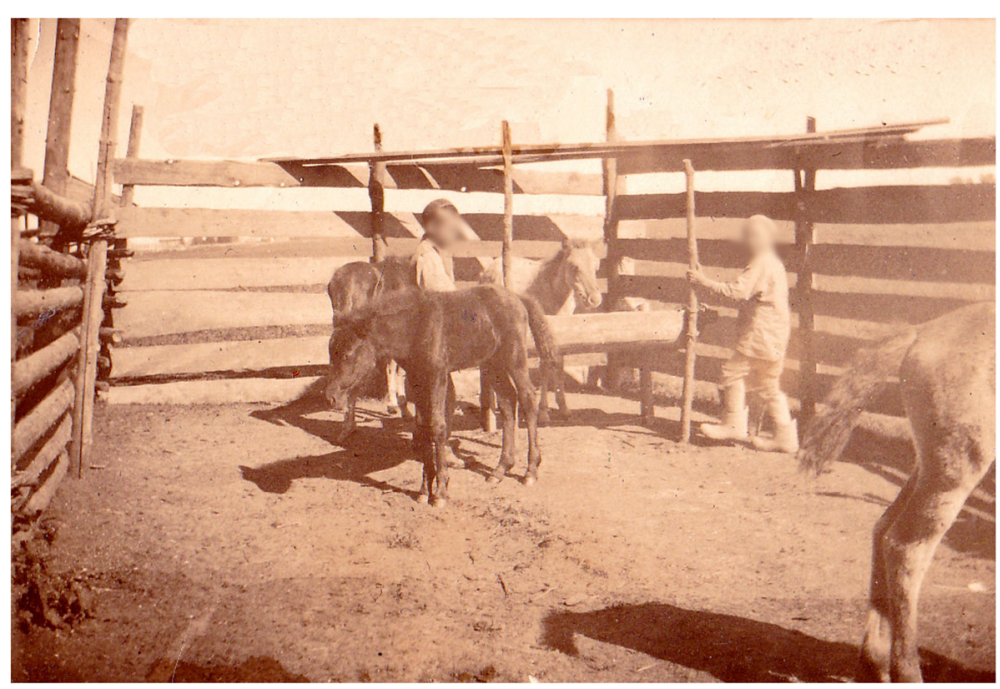

Fig. 2 Tatar boys with male foals. The photograph is from a kumys (fermented mare's milk) center behind the St. George Cemetery in the capital of the Russian Empire, Saint Petersburg. The picture was taken in the first half of the twentieth century. Fermented mare's milk has been a highly appreciated drink among the Tatars and several Central Asian peoples for centuries. The mares and the foals are separated so that the milking can take place. The boys are possibly set to guard the foals, but they also play with them. Renat Bekkin, private collection 


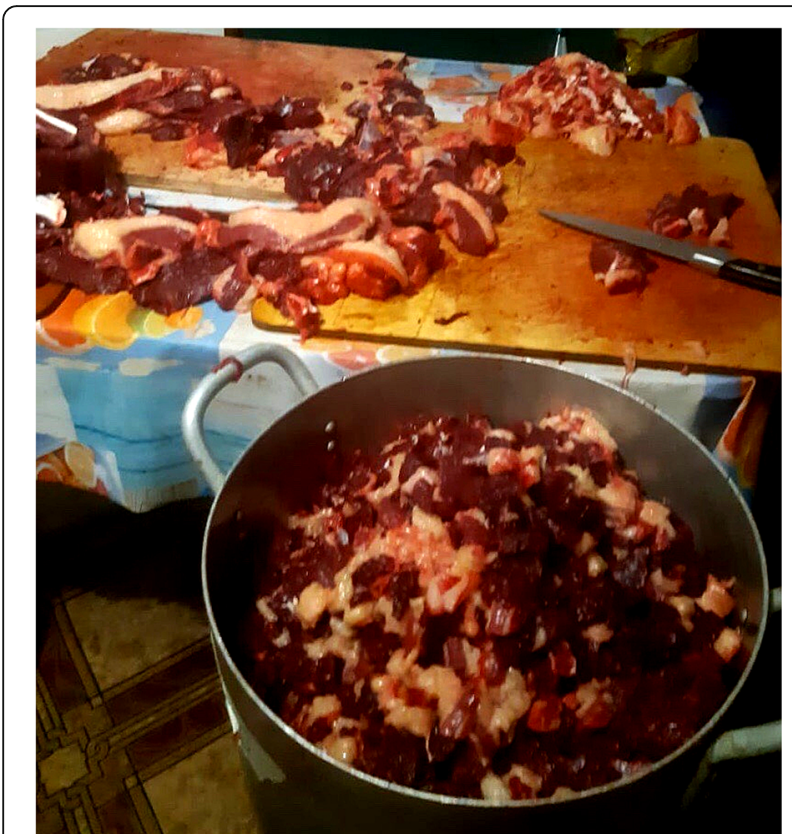

Fig. 3 Chopped horse meat is being prepared for sausages. In Petrjaksy village, Nizhny Novgorod province, a Tatar family prepares the contents for the sausages. The traditional dried horse sausage, kazy, is still very popular in the Mishär Tatar villages in Russia. In the village setting, the sausages are made by the family members with help from neighbors and friends. Urban Tatars and those living in the diaspora in Saint Petersburg and other large cities buy their sausages from meat shops. Those who have relatives or a house in a village can also get or prepare their own home-made sausages. Photo Elvira Umarova 2020

\section{Diaspora horse slaughter in Finland, Estonia, and Latvia}

Horses in Finland died in the nineteenth century of old age, poor care, or too much work. They were kept until they could not anymore perform their duties. Sometimes foals would be killed, if their owners could not sustain them, but it was not usual to consume horsemeat. Eating or skinning a horse was considered a sin for Finns. Dead horses were buried intact and a local skinner was called in to kill the horse. Both he and the dead horse were considered unclean. In urbanized twentieth-century Finland, animal protectors found the sale of old, injured or sick horses a cruel practice, and slaughtering horses was still highly controversial. During World War II, soldiers sometimes ate horsemeat, but not voluntarily, and the men avoided eating their own horses. After the war, horsemeat became more popular and slaughterhouses were set up, but many, especially peasants, still found hippophagy unethical [37]. A Finnish cookbook from 1939 has only one horsemeat recipe, but later cookbooks seldom have any. Horses in Finland are today mainly companion animals [38].

Special Tatar slaughterhouses were not established in Finland, but horses were slaughtered at home by the diaspora Mishär Tatars. Written sources are lacking, but in an interview [39], elderly Tatar N. tells about slaughtering in Järvenpää, north of Helsinki, in the 1950s. In early spring, when snow was still on the ground, a horse was usually slaughtered outside the family house. The children could be present and they were very fond of horse sausages, so they did not find the event scary. When horse blood flowed down the street, however, some children felt ashamed before their Finnish friends, who might react negatively. All Tatar families participated in the work of preparing the horse for food. An elderly neighbor performed the slaughter, assisted by the men, but also the women and children worked together to prepare the meat and different parts of the horse for food [39] (Fig. 4).

While Estonians preferred pork, Tatars who settled in the newly independent state of Estonia after World War I, continued to eat horsemeat. Injured horses were sold to the Tatars for slaughter. The meat was shared among the members of the Tatar community, including the poorer ones. The horsemeat was used to make sausages, which could be stored during the winter in the attic [32]. In Riga, Latvia, before World War II a Tatar used to buy horses and slaughter them for the Tatar community. The majority of the Latvians did not touch horsemeat, but other Muslims, probably mostly Tatars, bought the meat for food [5].

\section{Cultural adaptation: restaurants in Saint Petersburg}

In Saint Petersburg, horsemeat could be purchased in Tatar butcher shops. Each co-owner of a horse

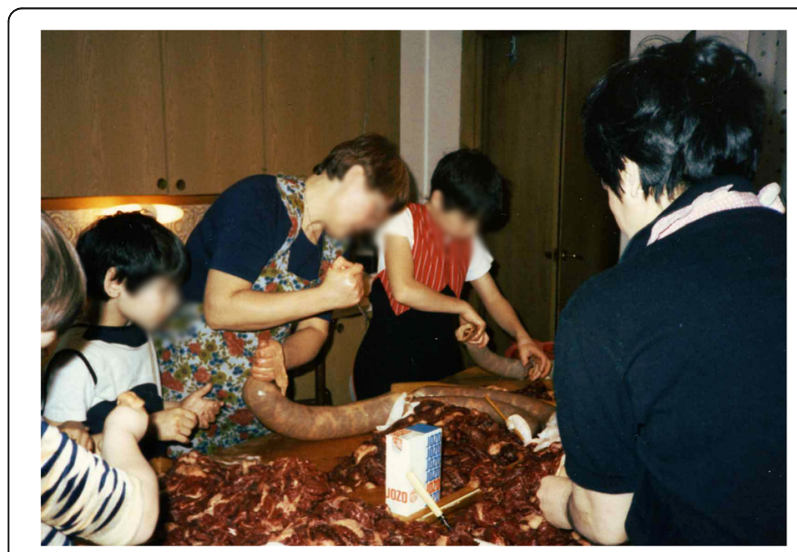

Fig. 4 Horse sausage making in Helsinki, Finland. Adults and children work together to fill meat into the washed horse intestines and making small holes with sticks in the sausages to let out air. The Mishär Tatar diaspora in Finland has for more than a century kept their food traditions. Horsemeat sausages are considered a delicacy, but they are also the result of joint effort. The adults transmit traditional knowledge and skills in cooking Tatar dishes by involving everybody in the process of preparing. The children observe and try their hand at every phase of the sausage preparation. The meat must be cut into suitable size and the intestines filled tightly, which requires training and experience. Photo Fazile Nasretdin 1986 
slaughterhouse near the village of Kupchino had for instance his own butcher shop [35]. Many of the shops were located in the area of the Five Corners (Pyat uglov), a quarter in Saint Petersburg with a dense Tatar population. Horsemeat was also served in special Tatar taverns (Russian kukhmisterskie). According to the magazine Our Food (Nasha Pischa) in 1893, there were two such taverns or eateries in the city. One of them was described as follows by a Russian writer:

The Eatery in Shcherbakov Lane is visited mainly by Tatars-khalatniks [traders], cabbies, Tatar peddlers, who sell either calico shawls or Kazan soap. The eatery bears no sign, but all Tatars know it. In fact, the Tatar eatery in Shcherbakov Lane is very dirty. You enter a small room, where tables are covered with unclean tablecloths: one could say about these tables and tablecloths with the words of Shchedrin that they looked as if "a child had been sitting there". To the left is another room intended for the beautiful representatives of the Mongol tribe - the black-eyed Tatar women. Without removing their scarves from their heads, the Tatar women sit in their half of the place, separated from the males. No man can enter there. The following dishes are served from the Tatar kitchen: 1 . horsemeat ravioli [Russian pel'meni] in the broth; 25 raviolis are cooked in the broth, which is one serving; 2. salma, which is nothing but our [Russian] dumplings in the broth; 3 . noodles in the broth [34]..

During the Civil War and famine in Petrograd (renamed from Saint Petersburg, later Leningrad) in 1918-1920, horsemeat was consumed not only by Tatars, but by the entire population of the city. Even selfdead horses were consumed. During the years of the New Economic Policy (NEP; 1921-1929), Tatars began to open horsemeat shops again. The trade of horses slaughtered according to the Muslim tradition was on the rise, but in the 1930s, when politics changed again, it declined. After World War II, horsemeat could be purchased at collective farm markets in Leningrad or unofficially through contacts [35].

In Moscow, horsemeat was sold both before and after 1917, and it was considered "pure" meat, that is permissible for Muslims. Tatars in Moscow could buy horsemeat and sausages in stalls and markets [39]. Moscow is however a separate topic, as the Mishär Tatars, who moved to the eastern Baltic Sea region, kept Saint Petersburg as their reference point.

\section{Traditional Tatar food in the modern context}

Traditional Mishär Tatar cuisine includes grains such as wheat and buckwheat, potatoes, milk products, meat, and vegetables [40, 41]. This village fare is today considered by many urban Tatars too heavy food, but in the rural areas south of the Volga River, traditional dishes are still prepared daily. A Tatar cookbook published in 1987 contains around a dozen horsemeat recipes. In addition to several sausages, horsemeat soups, casseroles, and fried horse fat recipes are presented [42]. The Internet offers a great variety of Tatar recipes for horsemeat [41] (Fig. 5).

Traditional horse meat recipes are for instance salted meat, aygyz (oygoz) from ribs and argamak, a piece of boiled-smoked foal (without bone), and a large intestine turned inside out and fried with fat. Kazy or sausage remains the main course prepared from horsemeat, possibly because it has always been cheaper than other products. Sausages are also easier to prepare, preserve, and distribute outside the village context, and the manufacturing technology can take into account various taste preferences of the consumers. Kazy can be served boiled, dried, raw-smoked, or boiled-smoked. Among Mishär Tatars from the Nizhny Novgorod province it is more customary to produce kazy in the dried and smoked forms $[40,42,43]$.



Fig. 5 Freshly made horsemeat sausages in Petrjaksy village, Nizhny Novgorod region. For the sausages, the most important thing is to store them in a suitable place. During the first night after preparation, the newly meat-filled intestines are left in the kitchen, where any excess liquid drops off. Then the horse sausages are stored in the attic, where they will dry and slowly get the right texture, color, smell, and taste. Usually, they are hung from the ceiling to get enough air. The sausages need several months to dry and mature before they can be eaten. If the sausages are not ready by the end of May, a night in room temperature in the kitchen will speed up the process. After maturing, the sausages can be kept in a newspaper in the freezer. Photo Elvira Umarova 2020 


\section{Economy: using the whole horse}

In Finland, village traditions brought into the Mishär Tatar diaspora from a couple of settlements in the Sergach district south of Nizhny Novgorod continued until some decades ago. Horsemeat was eaten boiled, salted, and cured, according to elderly Mishär Tatar N., who participated every spring in the preparations, and still sometimes prepares sausages from purchased horse meat [39]. Meat of lesser quality was cooked in a pot on the same or next day after slaughter. The stomach of the horse was thoroughly cleaned and fried with onions for a fatty dish, and the other internals such as liver were also used for food. Some parts of the horse, especially the more chewy ones, were minced and cooked. Bone parts could be used for soups, but it was not as tasty as the other horse dishes. Horse soup was not considered "fine food", but an everyday dish, not suitable to offer to guests (Fig. 6).

A quality steak was fried and eaten with bread. The meat was however mainly prepared for sausages, which was considered the most important horsemeat product. If the meat contained a lot of fat, the fat was cut away and not put into the sausage, but chopped into small pieces, salted and then melted. If meat pieces stuck to

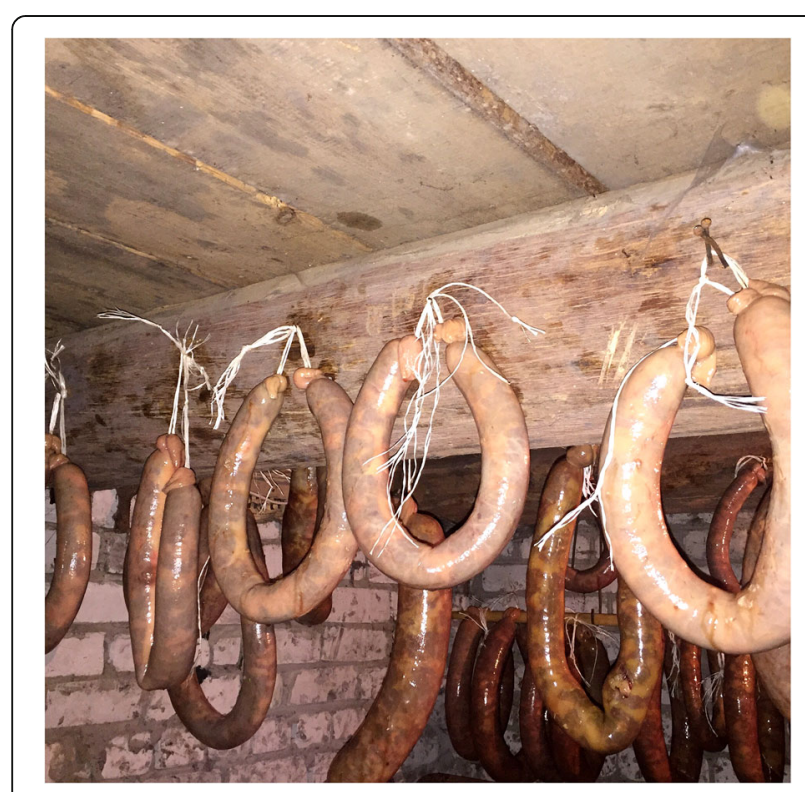

Fig. 6 Horsemeat sausages, kazy, need to dry in a cool place where air moves freely. They were traditionally prepared in winter or early spring, when snow was still on the ground. The men did the slaughtering, and the women and children prepared the meat, bones, internals, and other parts of the horse for different dishes.

The women kept the knowledge of how to cook and prepare horsemeat, but the men also joined in the work to prepare the sausages. Among Mishär Tatars, the gender division of work could be ignored when required. Women and men also eat horsemeat products together and not separately, like for instance among the Kazak. Photo Elvira Umarova 2020, Petrjaksy village, Nizhny Novgorod region the fat, they were fried with onion and the dish was called sızık. The fat pieces became softer than butter and yellow like honey, and they were eaten with dark rye bread. The fat was also used for frying peremech (pärämäç or pärämäts, a traditional Tatar pastry with meat), but the smell was so strong that even the neighbors knew that horse fat had been put into the pan $[39,41$, 44] (Fig. 7).

The intestines for making sausages were washed in several sets of water and turned inside out. The children sharpened wooden sticks for the ends of the sausages, from which the sausages would be hung. Salt and a little sugar were added to the meat, and after the 1950s sometimes also garlic. The clean intestines were cut into shorter pieces and filled tightly with meat. The intestines were pierced with the sticks, making small holes to let out air. The men did the final hard pressing of the intestines with a rolling pin, and bound the ends together. The sausages hang overnight, dripping in the kitchen. After that they were taken into the attic, where they dried for a few months in the cool winter and early spring air [39-41].

In late spring, usually at the end of May in Finland, the sausages had matured and were ready to be eaten. The family went up regularly to check on them. In houses with small holes for the attic, children were sent up every day by a grandmother or grandfather to check the state of the sausages, increasing their expectations. The surface must be completely dry and the sausage hard. If a sausage looked a bit raw, it was taken down to

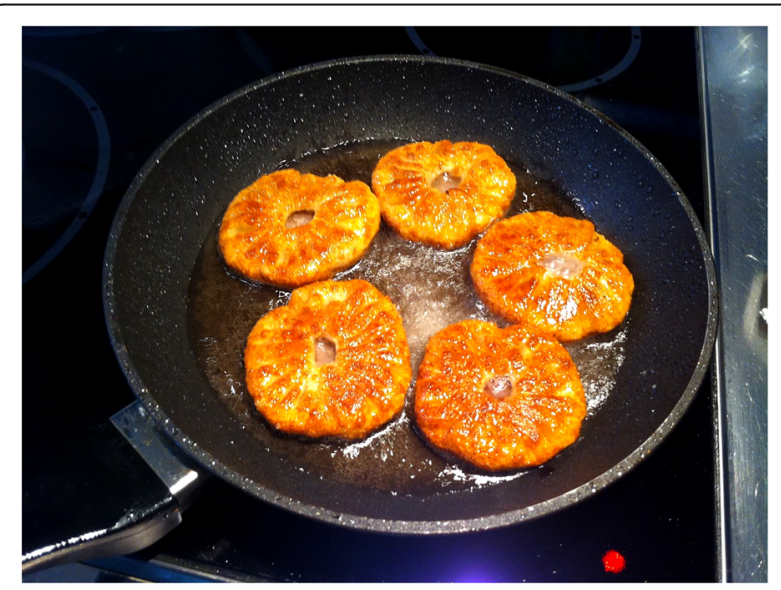

Fig. 7 A popular dish and important for the Mishär Tatar identity is pärämäç, also pronounced peremech or pärämäts. This pastry is filled with minced meat and chopped onion and a little salt and black pepper. The dough is rolled out into flat disks of $10-15-\mathrm{cm}$ radius. $A$ few spoons of meat mixture is added and flattened. Then, the edge of the disk is folded up neatly, leaving a small round opening. The round peremech pastries are either fried in a pan or oven-baked. Optionally, peremech is made with potatoes for a non-meat or lighter variation. Photo Fazile Nasretdin 1995 
the kitchen and in room temperature it would "mature". Horsemeat sausages were eaten with rye bread, a kind of salty doughnuts, or grains. The sausages could keep for a long time in a freezer and were usually wrapped in a newspaper. The sausages and the horsemeat were so popular in the household, however, that no sausage ever remained until the next year [39] (Fig. 8).

\section{Commensality: sharing food and work}

Horsemeat products and preparations have been shared among the Mishär Tatars in the Volga region at least for the past few centuries. In the diaspora communities horsemeat is connected with sharing, too. In the villages, families joined together for slaughter and preparations, and also for consumption. The Tatar community in Järvenpää, Finland, slaughtered a horse and made sausages and other horsemeat dishes jointly every year [39]. Everybody from the small and close-knit group helped with the slaughter and received a piece of the horse. Some families made only few sausages and others made several, depending on family size and knowledge of previous quantities consumed. Several dozen sausages were made for the interviewed N.'s family, which in addition to the parents and children consisted also of grandparents [39].

In contrast to some other Turkic peoples, such as the Kazak, Mishär Tatars do not separate women and men when consuming horsemeat. Gender rules and generation roles among the Tatars exist, but can be overruled according to the situation. Traditionally, after slaughter the men usually took care of the skin, and the women



Fig. 8 Horse sausage making in an apartment kitchen, Helsinki, Finland. The children participate actively from an early age in the work, filling the intestines with meat and making sticks for the ends of the sausages. The sticks are used to make holes in the sausages to let out air and also to fix the ends, from which the sausages are hung. The methods of sausage making among the Tatar diaspora in Finland remains very much the same as in the ancestral villages in the Volga region. Today, they have access to modern kitchen equipment, however, which facilitates and speeds up the preparation process. Photo Fazile Nasretdin 1986 cleaned and cooked the different parts of the horse. The meat was put on a covered kitchen table for preparing the sausages. Especially grandmothers were eager helpers and they would laugh and tell stories and jokes, making the process of sausage preparation an engaging and enjoyable event. When the children were old enough, they participated in cutting the meat into strips and removing ligaments. The young joined gradually in the adult activities as they became teenagers. Thus, every member of the community received thorough training in different aspects of horsemeat preparation and could transmit their knowledge and their skills to the next generations.

After the 1960s, horsemeat was increasingly bought from slaughterhouses and the tradition of home slaughtering disappeared. In Helsinki, the capital of Finland, the large community of Mishär Tatars most probably had to buy horsemeat from butchers or from Tatars in smaller towns, as there is no record of Tatar horse slaughter in the city. Home slaughter would also be impossible due to the urban environment-most of the Mishär Tatars lived in the city center-and stricter control. Today the Tatar community in Järvenpää sometimes still prepares horsemeat sausages together in the mosque kitchen, but the meat is bought from a shop. Less meat is used now, because dietary concepts and habits have changed and modernized, and diaspora Tatar cuisine has adapted to the availability of products in Finnish shops. Sausages are still a part of the Mishär tradition and evoke happy emotions and memories, but meat consumption has diminished and vegetable use increased in comparison with previous generations. The Tatar menu in Finland has been highly influenced by new ingredients, cooking methods and health considerations, and traditional food is at present mostly confined to celebrations and guests [39] (Fig. 9).

\section{Discussion}

\section{Connecting through food}

Until 1917, horsemeat was one of the main meat dishes for Mishär Tatars in the Russian Empire. Migrating into an urban context and into a diaspora situation, horse meat continued to be an important ingredient for Mishär Tatars. From the 1920s, horseflesh was consumed in the Soviet Union when there was a need, such as famine, or for pleasure, celebrations, or festivities, and naturally, when an opportunity to buy it appeared. In Finland, Estonia, and Latvia, horsemeat was either bought from butchers or horses were slaughtered by the Tatars themselves. At the beginning of the twentieth century, new ingredients and ways of preparation, utensils, and health recommendations have changed the now urbanized Tatar diet. Restaurants and the introduction of ethnic cuisines transform traditional Tatar cuisine, culinary training courses, and cookbooks reinvent dishes, and 


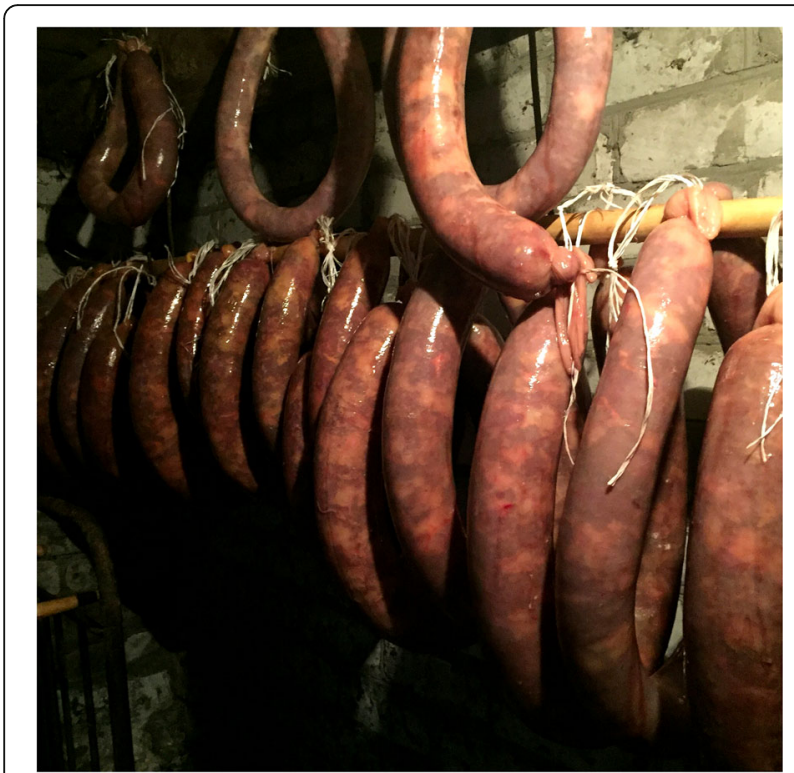

Fig. 9 Fresh horse sausages drying in the attic, Petrjaksy village, Nizhny Novgorod region. In the wooden village houses, the attic is used for drying the sausages and storing food. In the Volga region, the climate is very cold and dry in the winter, cool in the spring, and hot in the summer. The attic keeps cool until May-June, which makes spring a suitable period for preparing the sausages. In the diaspora and especially in city houses in Saint Petersburg or Finland, Estonia, and Latvia, storing the sausages is more complicated. Saint Petersburg and Helsinki, for instance, are both located by the sea, and humidity levels can be high. Photo Elvira Umarova 2020

students developed their own fast food versions of traditional dishes. In the eastern Baltic Sea region, consciousness about health issues has become prominent. Now, for instance, ready-made horseflesh products are a festive delicacy, shared by the Tatars in Saint Petersburg for celebrations [29, 30].

Mishär Tatar identity in the diaspora has for the past century developed from a self-concept based on rural traditions and networks to an urban minority identity. In the eastern Baltic Sea region, all Tatar communities are small, comprising at most a few thousand people; in Saint Petersburg, the number of Tatars (including others than Mishär) is estimated at around 30,000. Home slaughter of horses does not occur anymore, mainly because horsemeat is available in shops, but there are also more restrictions on slaughtering and dealing with meat products today. As a consequence, the community event of preparing horseflesh products has almost disappeared.

Still, Tatars consider horsemeat and especially sausages part of their tradition. Horsemeat products bring back pleasant memories and a feeling of belonging. Peremech, the fried or baked Tatar pastry usually prepared with minced meat, has a similar emotional and connecting effect. Just mentioning peremech can immediately create a bond between Tatars who meet for the first time [45].
Mishär Tatars who consume horsemeat can also connect and bond more easily than non-horsemeat-eaters with other Tatars, Kazak, Kyrghyz, Uzbek, Kalmyk, Mongolians, Siberian Turkic peoples, and others, who share the tradition of eating horseflesh [11, 44] (Fig. 10).

\section{Identity and sausages}

Most diaspora Mishär Tatars say they eat horsemeat, because they like it and connect it to family and community values, warmth, and happiness, being together and having a good time. Horsemeat has been a part of the diet, celebrations, and family and community activities since their childhood. They do not need to question if it is right or wrong to eat horseflesh, like the majority society does, because they have always consumed it. Positive attitudes and emotions toward eating horseflesh, originating in early memories and experiences of socializing within a close-knit community, contribute to their personal food choices $[28,43]$.

Another aspect is the usual respect for traditions and elders. Horsemeat is part of the Mishär Tatar tradition. What is its significance for the diaspora Tatar identity in the eastern Baltic Sea region, and does it contribute to conserve or create a specific Mishär Tatar identity? More than a century ago, horseflesh was the main meat dish for the ancestors. The generation who migrated from the village still slaughtered and prepared their own horsemeat products, but today food production has become industrialized and ready-made products such as

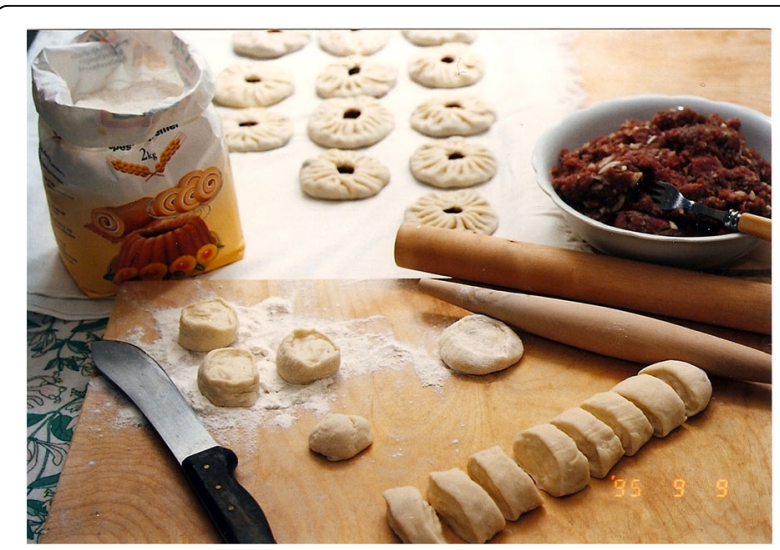

Fig. 10 Preparing peremech, the traditional Tatar pastry, is besides horsemeat sausages a joint activity, which brings Mishär Tatars together. Learning to fold the edge in the right way is a skill children acquire from an early age. Usually, peremech is prepared in big quantities by many people together for celebrations or guests. When Tatars meet, the talk often turns to food and eventually to peremech. Even just talking about the pastries awakens positive memories and feelings and brings Tatars closer to each other. Peremech pastries are consumed with sour cream or fat yoghurt, pickled cucumbers, or other pickled vegetables, but every family has their own preferences for the serving. Leftovers can be frozen, in the rare case there are any. Photo Fazile Nasretdin 1995 
kazy (horsemeat sausages) are available in ordinary or specialized shops, depending on the country and local market [46].

Horseflesh could fairly easily be consumed on a daily basis now, but it has become a dish for celebrations, rarely eaten, and special for the Tatars. The reason is probably that diets and cooking have changed, and more vegetables and other meats are available today. Still, horsemeat is one of the important aspects Mishär Tatars consider part of their cultural heritage. A celebration would not be complete without horse meat. Eating horsemeat brings the group, family, and community closer together and supports the (re-)creation and strengthening of a common identity, which is based on joint traditions, food habits, and cultural heritage, also when language or other identity markers are lacking [43] (Fig. 11).

\section{Non-adaptation to majority society}

The debate in Finland after the international 2013 horsemeat scandal was polarized between the topics safe/unsafe, ethical/unethical, sacred/profane, and human-like/ animal-like [47]. The social change is apparent: in agricultural Finland more than a century ago, horses were considered "real" horses; they were kept for practical and financial reasons. Today horses are companion animals [37]. The considerations, which shook Finnish society, have little or no significance for the Mishär Tatars. Eating horsemeat is a tradition and practiced,

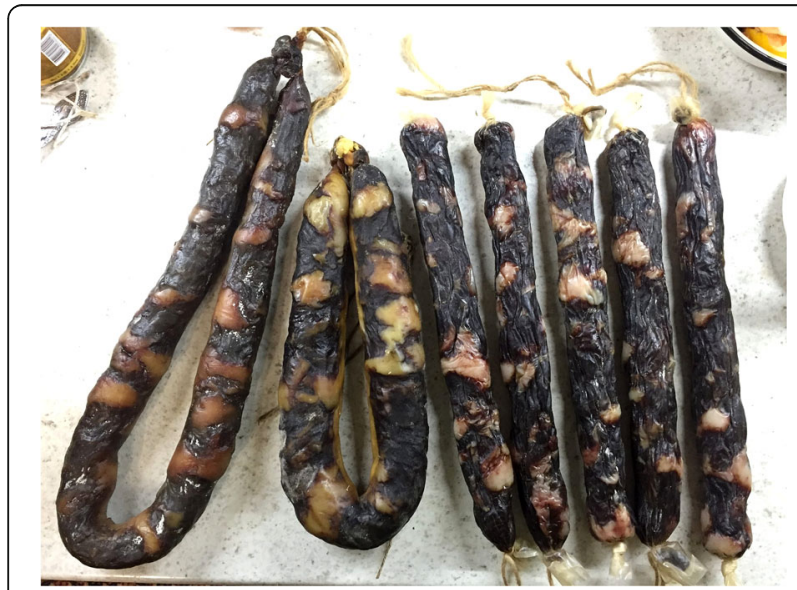

Fig. 11 Dried horse sausages, Petrjaksy village, Nizhny Novgorod region. After several months in the attic, the sausages are ready to be eaten. The sausages must be hard and dry before they are considered suitable for consuming. They are considered "mature" when they are hard enough. Children are sent up into the attic several times during April-May to check on the sausages, thus learning the right texture, color, and hardness. The sausages are cut into pieces and served in each family in the way they prefer, with potatoes, bread, or other dishes. Usually, no dry sausages are left when the next fresh sausages are prepared. Horsemeat sausages are considered a delicacy and they are a great favorite for all members of the Mishär Tatar household. Photo Elvira Umarova 2020 although not very openly declared, in the face of prejudices and negative reactions from the surrounding society. Several Tatars have close connections with horses, riding, breeding, or trading, but this does not stop them from consuming horseflesh products. In this aspect, they share the attitudes of other Central Asian and Siberian peoples, who see horses both as workers, companions, and food $[23,44]$.

Commensality, eating at the same table, or in this case eating food that is frowned upon or creating disgust among the majority, is an important trait in Mishär Tatar social activity. Eating together creates a feeling of stability and continuity, and the supposition that we become more similar to those with whom we join in the feast [23]. On the other hand, the Mishär Tatar form of commensality excludes the non-horse-eating majority. This creates a space, where Tatars can enjoy their own culture, language, and a friendly and understanding company. Nobody is required to explain who they are or why they eat horsemeat or other "strange" things, which create reactions among the majority. A free zone and a specific cultural dimension is created, where Mishär Tatars do not need to emphasize that they are well integrated, and behave like Finns, Russians, Estonians, or Latvians, but they can behave and be accepted like the Tatars they are [43].

\section{Conclusion}

Horsemeat consumption among Mishär Tatars is a tradition with strong emotional values and a highly social function. This hippophagy brings together persons, who carry similar attitudes to sharing, togetherness, and traditions. In the eastern Baltic Sea region, horseflesh has become a rare ingredient in the Tatar diaspora cuisine today. Cooking has changed under the influence of a broader product availability and new food habits. A hundred years ago, Tatar self-concepts, identities, and contacts were based on large families and village networks, but they have changed into urban identities and core families. Sixty years ago a community would still join in when slaughtering a horse, but now industrially prepared horse sausages create bonds and contribute to the concept and conservation of a specific Tatar identity in a minority situation. Horsemeat eating is seen as one of the characteristics of the Mishär Tatar cultural heritage, and it continues despite being frowned upon in the majority societies.

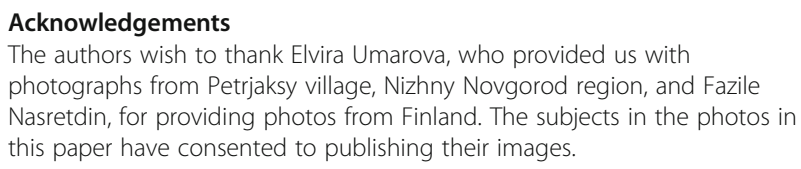




\section{Funding}

Not applicable.

\section{Availability of data and materials}

All data generated or analyzed during this study are included in this published article.

\section{Competing interests}

The authors declare that they have no conflicts of interest.

\section{Author details}

'Institute for Russian and Eurasian Studies, Uppsala University, Box 514, SE-751 20 Uppsala, Sweden. ${ }^{2}$ Institute of Oriental Studies at the Herzen State Pedagogical University of Russia, 191186Moika River Embankment, 48, St. Petersburg, Russia. Institute for African Studies of the Russian Academy of Sciences, 123001, Spiridonovka Str., 30/1, Moscow, Russia.

Received: 17 March 2020 Accepted: 28 October 2020

Published online: 07 November 2020

\section{References}

1. Kwon DY. What is ethnic food? Journal of Ethnic Foods. 2015;2(1):1. https://doi.org/10.1016/j.jef.2015.02.001.

2. Simoons FJ. Eat not this flesh: food avoidances from prehistory to the present. Madison: University of Wisconsin Press; 1994

3. Fieldhouse P. Food and nutrition: custom and culture. Springer-Science: 1995.

4. Gade DW. Horses. In: Kiple KF, Ornelas KC, editors. Cambridge world history of food. Cambridge: Cambridge University Press; 2000. p. 542-5.

5. Egardt B. Hästslakt och rackarskam. Nordiska Museet: Stockholm; 1962.

6. Brøndegaard VJ. Folk og fæ. Dansk husdyr etnologi 1. Rosenkilde og Bagger: København; 1995.

7. Bergstrand CM. Om hästslakten och dess utövare i 1800-talets Västergötland. Folkminnen och folktankar. 1932;19:50-62.

8. Barth F. Introduction. In: Barth F, editor. Ethnic groups and bounderies: the social organization of culture difference. Bergen: Universitetsforlaget; 1969. p. 9-38.

9. Svanberg I. Hästslaktare och korgmakare: resursutnyttjande och livsstil bland sockenlappar. Johan Nordlander-sällskapet: Umeå; 1999.

10. Balassa I, Ortutay G. Ungarische Volkskunde. Corvina: Budapest; 1982.

11. Svanberg I. Kazak refugees in Turkey: study of cultural persistence and cultural change. Almqvist \& Wiksell Interational: Uppsala; 1990

12. Eidlitz K. Food and emergency food in the circumpolar area. Almqvist \& Wiksell Interational: Uppsala; 1969.

13. Potapov LP. Food of the Altaians (ethnographic essay) [in Russian]. In: Sbornik muzeya antropologii i etnografii 1953; XIV:37-71.

14. Bergius B. Tal, om läckerheter, Både i sig sjelfva sådana, och för sådana ansedda genom Folkslags bruk och inbillning. Stockholm: Johan Georg Lange; 1785.

15. de Beauplan WV. Beschreibung der Ukraine, der Krim und deren Einwohner. Aus dem Französischen übersetzt und nebst einem Anhange der die Ukraine, und die Budziackische Tataren betrifft, und aus dem Tagebuche eines deutschen Prinzen, und eines Schwedischen Kavaliers gezogen worden. Breslau; Wilhelm Moeller; 1780

16. Byhan A. Die Türkvölker Ostrusslands. In: Buschan G, editor. Illustrierte Völkerkunde 2. Stuttgart: Strecker und Schröder; 1926. p. 844-908.

17. Bergmann B. Nomadische Streifereinen unter den Kalmücken in den Jahren 1802 und 1803. CJG Hartman: Riga; 1804.

18. Falk JP. Beyträge zur Kenntnis des Russischen Reichs Bd 3. Kaiserlichen Akademie der Wissenschaften: St. Petersburg; 1786

19. Falk JP. Beyträge zur Kenntnis des Russischen Reichs Bd 1. Kaiserlichen Akademie der Wissenschaften: St. Petersburg: 1785.

20. Erdmann F. Ueber die Tataren Kasans. Zeitschrift der Deutschen Morgenländischen Gesellschaft. 1859;13(4):659-90 742.

21. Rohrlich A-A. The Volga Tatars: a profile in national resilence. Stanford: Hoover Institute Press; 1986.

22. Svanberg I. Tatars. In: Cole JE, editor. Ethnic groups in Europe: an encyclopedia. Santa Barbara, CA: ABC-CLIO/Greenwood; 2011. p. 362-5.

23. Kerner S, Chou C. Introduction. In: Kerner S, Chou C, Warmind M, editors, Commensality: from everyday food to feast. London: Bloomsbury Academic; 2015. p. 1-9.

24. Medeiros MFT Historical ethnobiology. In UP Albuquerque, RRN Alves (eds.) Introduction to ethnobiology. Cham: Springer International Publishing; 2016: $19-24$.
25. Higgin M, Evans A, Miele M. A good kill: socio-technical organisations of farm animal slaughter. In B. Carter, Charles N. (eds.) Humans and other animals: critical perspectives. London: Palgrave Macmillan; 2011: 173-194.

26. Field observations and interviews in Mishär Tatar villages in Nizhny Novgorod province, Russia, by Sabira Ståhlberg, October-November 1999.

27. Interview with N., by Sabira Ståhlberg, Järvenpää, November 2018.

28. Lepa E. "The Tatar way" of understanding and practising Islam in Estonia. Studia Orientalia Electronica 2020: Volume 8(2): 70-81. DOI 10.23993/store.82938.

29. Gabdrakhmanova G.F. The modern market of halal meat products among the Tatars [in Russian]. In: Etnographicheskoe obozrenie, 2011; 1: 37-47.

30. Gabdrafikova LR. Food culture of urban Tatars (late $19^{\text {th }}$ - early 20th centuries) [in Russian]. In: Etnographicheskoe obozrenie. 2013;2:138-49.

31. Nurmukhametova R, Sattarova M. Social, cultural and natural factors in formation of the Tatars culinary vocabulary. Mediterr J Soc Sci. November 2015:6(6):55-9.

32. Abiline T., Ringvee R. Estonia. In I. Svanberg, D. Westerlund (eds.), Muslim Tatar minorities in the Baltic Sea region. Leiden: Brill; 2015: 125-127.

33. Bekkin R, Ståhlberg S. Saint Petersburg. In: Svanberg I, Westerlund D, editors. Muslim Tatar minorities in the Baltic Sea region. Leiden: Brill; 2015. p. 67-85.

34. Bekkin Rl., Tagirdzhanova AN. Muslim Petersburg. Historical guide-book [in Russian]. Moscow - St. Petersburg: Institut Afriki RAN; 2016: 365.

35. Bekkin RI. Tatars in St. Petersburg: horse-slaughtering industry (XIX - early XX centuries) [in Russian]. Ekho vekov. 2015;3-4:260-3.

36. Bakhtiyarov AA. The Belly of St. Petersburg. Social and physiological essays [in Russian]. Saint Petersburg: F. Pavlenkov; 1888: 230.

37. Schuurman $\mathrm{N}$, Leinonen RM. The death of the horse: transforming conceptions and practices in Finland. Humanimalia: A Journal of Human/ Animal Interface Studies 2012; 4(1): 59-82.

38. Koskimies H, Somersalo E. Keittotaito. WSOY: Porvoo; 1939.

39. Safarov M. Compliance with halal traditions in the Moscow Muslim community: modern tendencies [in Russian]. Journal Tatarica. 2015;5.

40. Akhmetzjanov JA, Mukhamedova R, Bikbulatova K, Ivanova R. Cuisine of the Tatar people [in Kazan Tatar]. Tatarskoe knizhnoe izdatel'stvo: Kazan; 1987.

41. Sausage horse Tatar recipe. How to cook kazy. Kare18. https:/kare18.ru/en/ kak-prigotovit/kolbasa-konskaya-tatarskaya-recept-skolko-varit-kazy/ (accessed 2020-03-06).

42. Mukhamedova RG. Mishar Tatars: historical and ethnographic research [in Russian]. Moscow: Nauka; 1972

43. Sabira Ståhlberg, Field notes.

44. Peemot VS. We eat whom we love: hippophagy among Tyvan herders. Inner Asia 2017; 19(1): 133-156. https://doi.org/10.1163/22105018-12340082.

45. Ståhlberg S, Svanberg I. Sweden. In: Svanberg I, Westerlund D, editors. Muslim Tatar minorities in the Baltic Sea region. Leiden: Brill; 2015. p. 145-58.

46. Gabdrakhmanova FK, Sattarova MR, Nurmukhametova RS. Traditions and customs as means of formation of eating behavior of Tatar people. Journal of Language and Literature. 2016;7(2):169-72.

47. Jaskari M-M, Leipämaa-Leskinen $H$, Syrjälä H. Revealing the paradoxes of horsemeat: the challenges of marketing horsemeat in Finland. The Nordic Journal of Business. 2009;64(2):86-102.

\section{Publisher's Note}

Springer Nature remains neutral with regard to jurisdictional claims in published maps and institutional affiliations.

Ready to submit your research? Choose BMC and benefit from

- fast, convenient online submission

- thorough peer review by experienced researchers in your field

- rapid publication on acceptance

- support for research data, including large and complex data types

- gold Open Access which fosters wider collaboration and increased citations

- maximum visibility for your research: over $100 \mathrm{M}$ website views per year

At BMC, research is always in progress.

Learn more biomedcentral.com/submissions 